\title{
Examples of financing innovative projects
}

\section{Joanna Wodzyńska, Rafał Czyżewski}

\begin{abstract}
Purpose

This article was written in order to characterize the innovative activity of enterprises in terms of its financing sources. Obtaining sufficient fundsis a basic requirement for undertaking any investment activity and it largely determines the further investment process and related decisions. An analysis of the available sources of financing indicates the interdependence between the innovation's subject area and the structure of its financing. The functioning of two selected companies dealing with the implementation of innovative products will serve as an illustration of both the theoretical and practical aspects of financing innovative projects.
\end{abstract}

\section{Design and methodology}

The paper hypothesizes that the financing of modern innovations requires flexible conditions and high level of capital,as verified by literature review and analysis of innovative products and companies.

The article consists of three parts. The first defines the concept of innovation and characterizes individual types of innovation: technological, organizational and social. Also discussed are the characteristic features of the phenomenon of innovation, the conditions shaping itand the impact it has on economic growth.

The second part is a review of existing sources of capital and methods of raising it through market and public instruments. Also discussed are the conditions for the use of individual instruments, depending on the stage of enterprise development, as well as their potential advantages and limitations from the entrepreneur's point of view.

The third part analyzes innovative products and companies responsible for their creation and development: the self-driving vehicle created by the American company Tesla Inc. and a thermographic tester for oncological diagnostics created by the Polish company BRASTER.

\section{Findings and implications}

Innovation belongs to the developing field of economy and economics. Statistical and econometric studies prove that, due to the significant risk level, innovation needs to be stimulated. Its development has a positive impact both on GDP growth and living conditions. However, in order to keep up with the technological frontier, it is necessary to under take appropriate actions serving to reduce the technological gap.

This is why financing innovation is a complex process, requiring a flexible approach. And there is a considerable variety of financial instruments dedicated to innovations offered by market entities and by state institutions. 
This theoretical work is illustrated with examples of companies implementing technologically sophisticated products. Tesla Inc. finances work on the self-driving vehicle by increasing operational obligations, issuing debt securities, additional capital contributions and even the sale of $\mathrm{CO}_{2}$ emission rights. On the other hand, BRASTER SA, while working on introducing the oncological tester on the market, accumulated capital as a result of large issues of shares and taking out bank loans, which indicates that the company is just learning investment processes.

Key words: innovation, financing innovative projects, autonomous car, thermographic oncology tester

\section{Defining innovation}

Globalization requires that countries and international organizations undertake actions which will help them create a competitive advantage or at least find their own niche in the open market. The current saturation of the market, as well as low shipping costs and the ability to compare products from different continents on the internet, demand non-standard activities that can reduce production costs, distinguish a product or create new demand for a good or service.

J. A. Schumpeter, the first theoretician of innovation, presented it as a "discontinuous process of creative destruction" resulting from the discrepancies of open market systems that requires ad hoc activities and creates new combinations of factors of production [Druker 1992, p. 35]. Contemporary academic and industry studies provide various definitions of innovation. According to the definition of S. Kasprzyk, innovation is an unknown method of satisfying new needs [Brzeziński 2001, pp. 19-20]. In W. Świtalski's words, innovation is a set of measures that help to improve the efficiency of economies, build a competitive advantage and obtain financial benefits [Świtalski 2005, p. 145]. Nevertheless, innovative ideas are the result of a creative process understood as the ability to associate unrelated issues. Scientists estimate that creativity develops mainly in cities [Waresa, Kowalski 2018, p. 253].

It is estimated that only about $2-10 \%$ of research processes are successful, i.e. result in the introduction and distribution of a new product on the market. Only after such implementation of an innovation is completed is its diffusion between enterprises and countries possible. And this is the stage that brings economic, ecological and social effects. Moreover, diffusion can contribute to reducing the technology gap which is closely linked to the income gap [Kubielas 2009, p. 137]. Even so, innovation creates a lasting competitive advantage for individual countries, and allows to avoid the middle income trap (as South Korea did).

The theory of economics does not determine exactly how to finance innovation in order to effectively influence development. Nevertheless, it is now anticipated that more than $30-40 \%$ of public funding can displace private investment. This means that capital accumulation (i.e. savings) is necessary to ensure economic growth, i.e. societies that are less willing to save are slower in development. However, the willingness to save is in no way related to asociety's wealth. 
Indexes and ranks are a way to compare the level of innovation in economies. The most important index for Europe is the European Innovation Scoreboard. Poland is assessed as a "moderately innovative" country thatis „falling behind" [Gorzelak, Bączkowski, Kozak, Olechnicka 2006, p. 183] and unable to create crucial innovations but only implement and improve imitations. The report is further refined by the Regional Innovation Scoreboard, in which individual Polish regions are assessed according to the Regional Innovation Index (RII). This indicator is on average correlated with their GDP (at the level of 0.33) which means that it reflects relatively well the regions' potential, although their development is probably still based on an increasing efficiency.

There is a statistically significant correlation between the number of clusters, technology parks and business incubators operating in the regions and the number of registered patents (0.48). The correlation between the number of clusters is strong (0.6). In Poland, the number of patents per capita is some twenty times lower than in Western European countries [Gorzelak, Bąkowski, Kozak, Olechnicka 2006, p. 183]. In this context, public institutions ought to support innovative activities in cooperation with these entities.

The level of economic development (GDP) also had an impact on the number of patents registered in Poland in the years 2003-2017. It turns out that entrepreneurs are very flexible and their innovation activity is limited during an economic downturn. They increase their inventive activity during a period of prosperity, when they have free resources at their disposal.

Eurostat conducts its own research on innovation inselected European countries. The results are released in the Community Innovation Survey (CIS). The last report emphasizes the importance of all enterprise improvements, an indicator of which is the number of patents held [Gomułka 1998, p. 82].

Innovation in different fields: technological, organizational and social, has developed independently, because economic theories and mathematical models describing them do not include all the market discrepancies that may disturb this development. Still, the development of innovation may increase an economy's resistance to disturbances resulting from asymmetric demand shocks because of the increased mobility of factors of production (i.e. capital).

Technological innovation activities created by education, research, publication and broadcasting of information have been dubbed the "fourth sector" of the economy [Piech 2009, p. 288] in which knowledge, innovation and entrepreneurship coexist (knowledge alone, without practical use, does not contribute to economic growth). The science-intensive and specialized supplier sectors are considered to be the most innovative while process innovations depend on product innovations taking place in the branches of suppliers [Gomułka 1998, p. 19]. Innovative companies must incorporate both imitation and pioneering activities in their strategies [Brzeziński 2001, p. 314], as imitation is usually simpler, cheaper and more reliable [Brzeziński 2001, p. 274]. However, until imitation appears, the natural monopoly of novelty gives a higher margin and technology bonus (up to $25-50 \%$ ). Since the standard level of investment in industrial innovation does not exceed $15-20 \%$, technical innovation should 
be stimulated so that it is possible to keep up with the constantly moving technological border [Kubielas 2009, p. 372]. Diffusion may only widen the technological gap between economies, because less developed countries are unable to absorb the sophisticated technologies. It is estimated that in the USA production increases by an average of $60-80 \%$ as a result of implementing research and development results [Brzeziński 2001, p. 26]. The strategy of increasing absorption capacity faster than reducing the technology gap has contributed to the success of the Asian tigers [Kubielas 2001, p. 251]. NVidia is an example of such technological success. The founders of the company, which produces 3D graphics systems, studied at the University of Utah, where research on rendering of 3D image and flight simulators was carried outwhile at other universities such opportunities were only being discussed during lectures [Rumelt 2013, p. 262].

Organizational innovations depend heavily on the transformation of business activities. This concept includes both changes in the formal organization of work (e.g. a team matrix or creative "no-collar workforce" factories), as well as innovative marketing strategies. Still, creating a coherent strategy requires a good knowledge of the industry, and investment in knowledge is sustainable. The OECD estimates that an additional year of education increases economic growth in the long term by $2.5 \%$ [Piech 2009, p. 272]. This is important, because, according to American research, enterprises are moving to places where there are lots of creative, talented and educated people [Florida 2010, p. 22].

Social innovations are based on technological and organizational innovations as new products and work culture change people's habits. It is estimated that as much as $80 \%$ of technical progress improves living conditions [Brzeziński 2001, p. 26]. Research has also shown that qualitative and quantitative changes in societies can be introduced intentionally. Social innovations are currently used to create trends for innovative products and activities. Increased demand creates a friendly environment in which enterprises have a higher demand for sophisticated technologies.

\section{Summary}

Innovation belongs to the dynamically developing field of economy and economics. Statistical and econometric studies prove that due to the significant risk involved in innovative activities, it is necessary to stimulate this field. Its development has a positive impact both on GDP growth and improvement of living conditions. However, in order to keep up with the technological frontier, it is necessary to undertake appropriate actions serving to reduce the technological gap. These activities should include both imitation, which is usually simpler, cheaper and more reliable, as well as pioneer activities that give a higher margin and technological bonus (up to 25-50\%).

Indexes and ranks are a way to compare the level of innovation in economies. The most important index for Europe is the European Union Innovation Scoreboard. Eurostat conducts its own research on the innovation of selected European countries. The result of this research is the Community Innovation Survey (CIS) which underlines the importance of all company improvements. 
The fields of innovation are: technological, organizational and social. Technological innovation activities have been called the "fourth sector" of the economy in which knowledge, innovation and entrepreneurship coexist. Organizational innovations base on the transformation of business activities through changes in formal work organization (e.g. the team matrix or a creative no-collar workplace), as well as innovative marketing activities. In contrast, social innovations often happen automatically when innovative products or a change in the organization and culture of work are introduced, but they can be implemented as part of social projects.

\section{Sources of financing innovative projects}

Finding sources of financing for innovative projects can often be a significant challenge for an entrepreneur due to the increased level of risk accompanying investing in innovative activity and the increased demand for capital. The amount of financial resources required for innovation depends primarily on the type of economic activity, the specificity of the industry, the availability of the company's own funds and the possibility of obtaining alternative sources of financing. Implementation of innovative projects requires the allocation of significant financial resources for research and development, implementation and marketing campaigns aimed at familiarizing potential customers with a novelty, which makes it difficult to raise capital on the financial market and forces them to reach for instruments other than those used in „ordinary” projects investment [Głodek, Pietras 2011b, p. 7].

The financial needs of innovative enterprises change, depending on the stage of the innovation process and the situation of the enterprise and its macroeconomic environment [Kokot-Stępień 2016, p. 16]. The initial stage of project evolution is characterized by low investment value and a high level of risk, which significantly reduces the availability of external financing. After that stage new possibilities are accessible: business angels, bank loans, public support, investment funds, capital market offer and crowdfunding.

Below is presented a review of possible sources of financing. However, it should be remembered that it does not include an important but difficult to estimate element, i.e. the contribution of an entrepreneur's own work, the cost of establishing business contacts at conferences or attracting direct investors.

\section{Market instruments}

The basic source of financing innovative activity in Poland is the use of own funds (i.e. retained earnings, share capital or supplementary capital), which is largely due to the limited access to external sources of financing and the high cost of their acquisition, as well as the relatively low propensity of entrepreneurs to risk, despite relatively cheap loans [Kokot-Stępień 2016, p. 22]. However, financing investments from one's own resources has a positive impact on efficiency because entrepreneurs are more willing to choose riskier but 
more efficient investments. Self-financed investment also reduces the costs of raising capital and servicing debt and allows for greater independence [Nehrebecka, Białek-Jaworska 2015, p. 73].

Investment loans are another significant source of financing for innovative activities. The advantage of this method of raising capital is the high availability of credit offers. On the other hand, the use of an investment loan is connected with the need to authenticate the project's profitability and ability to obtain a market position, which means that loan offers are directed mainly to mature projects [Głodek, Pietras 2011a, p. 27].

The initial stages of the development of an innovative product can be financed by venture capital investments, in particular through seed capital funds and "business angels"- private investors with experience, expertise and capital who are ready to invest in ideas with high potential, counting on an above average rate of return [Szul 2011, pp. 324-325]. Cooperation with business angels is particularly attractive for beginners because the investor also provides the company with his knowledge, experience and industry contacts.

Enterprises implementing innovative projects at the product or service implementation stage may decide to raise capital by issuing shares or bonds. The stock market is a place where purchase and sale transactions are carried out, where an act of ownership to a part of the enterprise (shares) or the right to specific benefits (bonds) can take place. On the Warsaw Stock Exchange, the NewConnect market is addressed to young, innovative companies due to lower capital requirements and simplified procedures [Głodek, Pietras 2011b, p.60]. The stock exchange debut provides benefits through ensuring investment capital, increasing the company's credibility and recognition as well as obtaining objective market valuation. However, there are also significant costs, for example the need to prepare reports on the company's operations, increased susceptibility to economic fluctuations or risk of loss of control over an enterprise [Kuciński 2011, p. 209].

Crowdfunding is a specific form of innovation financing, which has gained a significant position in recent years. This concept should be understood as "the accumulation and allocation of capital transferred for the development of a given venture in exchange for a specific repayable benefit, which involves a wide range of capital donors, characterized by the use of internet and a lower entry barrier and better transaction conditions than generally available on the market" [Król 2013, p. 22]. In practice, it involves organizing fundraising through web portals, where persons interested in a project pay relatively small amounts. A significant part of projects financed through crowdfunding are enterprises that can be classified as innovative. According to the statistics of the most popular Kickstarter platform, USD 1.684 billion was allocated to technology and design projects which accounts forover $41 \%$ of the total funds collected through this platform. 


\section{Public instruments}

Companies can usually use private financing as well as public instruments.This results from the high level of risk associated with investments in innovative projects and the related lack of sufficient market incentives that would encourage to undertake innovative activities [Kawalec 2017, pp. 65-77]. On the other hand, it is an expression of the aspiration of public institutions to shape existing markets and create new one sin order to achieve the goals set by political decision-makers [Kawalec 2017, pp. 65-77]. According to data of the Polish Central Statistical Office, in 2015-2017, 22.1\% of industrial enterprises and $17.9 \%$ of service enterprises received financial support for innovation activities [GUS 2018, p. 73].

Public financial support for innovative activities may come from both domestic and foreign institutions. Of key importance are programs financed with the participation of funds from the European Union :

- three operational programs: Intelligent Development, Knowledge Education Development and Eastern Poland,

- $\quad$ the Horizon 2020 framework programs and COSME.

The Intelligent Development OP aims to support the implementation by enterprises of industrial and experimental research aimed at developing new or improving existing solutions, including the preparation of experimental prototypes and pilot installations. Entrepreneurs can make use of a number of financial instruments, such as support for the creation of enterprises based on innovative ideas ("pre-incubation"), capital provision for newly established companies using venture capital funds, syndicated financing by business angels and start-up loan instruments focused on the commercialization of research and development results.

Innovative activity is also supported by the Knowledge Education Development OP. Under the "Social innovations and transnational cooperation" priority axis, institutions and other entities, including entrepreneurs, can receive funding to develop and test new solutions to problems existing in the area of the labor market, social integration, lifelong learning, health and modernization of public administration [POWER 2014-2020, 2018, pp. 29-30].

The Eastern Poland OP is an instrument serving to support the socio-economic development of the following regions: lubelskie, podkarpackie, podlaskie, świętokrzyskie and warmińsko-mazurskie. As part of this program, start-up platforms are created for new ideas, i.e. packages covering business, marketing and technological services. The program also provides subsidies for micro, small and medium-sized enterprises operating at a supraregional level [Szczegółowy opis osi priorytetowych POPW 2014-2020, 2019, pp. 10-18].

The basic framework program for innovation is Horizon 2020 - the Framework Program for Research and Innovation. As part of Horizon 2020's seven-year budget, around EUR 80 billion is planned to be distributed through instruments such as loans, guarantees, counterguarantees and equity financing for enterprises, public and private research institutions and organizations and universities. 


\section{Summary}

Finding sources of financing for innovative projects can often be a significant challenge for an entrepreneur due to the increased level of risk accompanying investing in innovative activity and the increased demand for capital. The amount of financial resources required for innovation depends primarily on the type of economic activity, the industry, the availability of the company's own funds and the possibility of obtaining alternative sources of financing. Thus, financing innovation is a complex and multi-stage process, requiring a flexible approach. A wide variety of financial instruments dedicated to innovations is offered by market entities and state institutions.

A company's own funds and investment loans hold a significant position among the sources of financing innovative activities. The initial stages of the development can also be financed by venture capital investments, in particular through seed capital funds and "business angels". On the other hand, enterprises implementing innovative projects at the product or service implementation stage may decide to raise capital by issuing shares or bonds, e.g. on the NewConnect market (on the Warsaw Stock Exchange) which is addressed to young, innovative companies due to lower capital requirements and simplified debut procedures. Crowdfunding is a specific form of innovation financing which has been gaining significance in recent years as a supplement to the above.

Companies can usually use private financing as well as public instruments. Accessibility of public sources of funding eliminates the problem of the lack of market stimuli that would encourage entrepreneurs to undertake risky innovative activities. In addition, it allows for existing markets to be shaped and new ones to be created in order to keep up with the technological frontier. Public financial support for innovative activities may come from both domestic and foreign institutions. Of key importance in this case are programs financed with the participation of funds from the European Union:

- three operational programs: Intelligent Development, Knowledge Education Development and Eastern Poland,

- $\quad$ the Horizon 2020 framework programs and COSME.

\section{Examples of financing innovative projects}

\section{The self-driving vehicle}

The Tesla Motors start-up was established in 2003 in Silicon Valley. From the beginning, the intention of its founders was the production of electric cars. Industrial research was carried out until 2008, when the production of the Roadster brand began. Tesla Motors achieved incredible success in 2013 which was reflected in an increase in the share price to USD 200. Tesla electric cars are characterized by a strong set of batteries which guarantee covering a distance of about $400 \mathrm{~km}$ on one charge. The product was first addressed to 
wealthier customers and only later were cheaper basic versions introduced. And so a brand representing prestige and a high standard of living was developed to be next offered to the aspiring middle class.

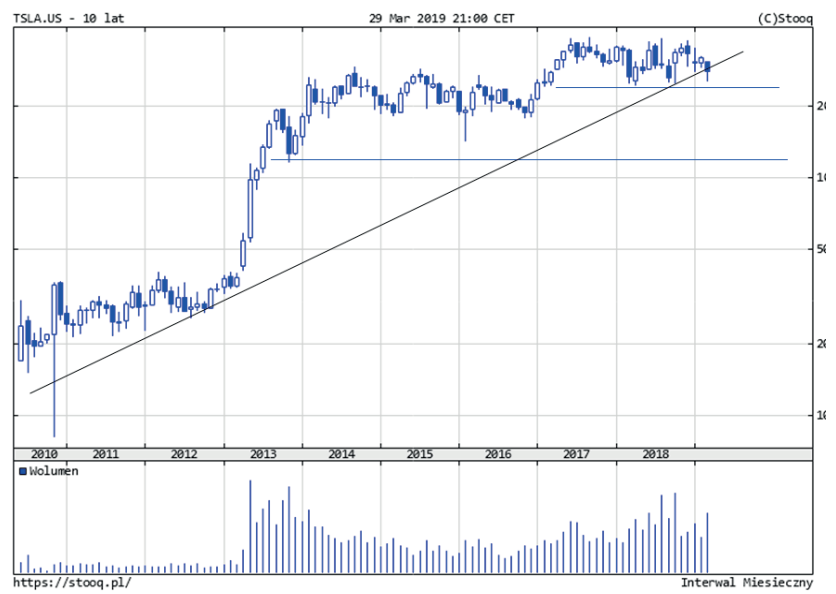

Fig. 1. Tesla share prices in the period 2010-2019

Source: stooq.pl website [https://stooq.pl/q/?s=tsla.us, accessed on 29/03/2019]

Technical analysis is used to assess assets that are characterized by high liquidity [Dąbrowska-Gruszczyńska 2017, p. 109] and short periods - up to 50 days [Reuters 2001, p. 21]. However, the chart above (Fig. 1) clearly shows the long-term upward trend [Reuters 2001, p. 123]. The last candle breaks out of this trend, but confirmation is still needed. The company's share prices have been moving in a medium-term sideways trend since 2017. If there is no exit from consolidation, the company is likely return to the long-term upward trend and set a new price maximum.

Tesla Motors has not limited its activities to electric cars. After achieving success, they became involved in another project. In models produced since 2014, it was possible to install the active collision prevention system and the Autopilot system. In the same year, it was announced that work on a self-driving vehicle had started. According to recent press information, the first model is to be produced as soon as 2019. At the same time, the Autopilot system is to provide the possibility of installing the self-driving system in earlier versions of Tesla cars.

Tesla Inc. is far ahead of the competition. Google, BMW or Uber plan to introduce their own self-driving vehicle brands no earlier than 2025.

The heart or operating system of the Tesla Inc. self-driving vehicle is based on the NVidia Drive PX 2 system (a front radar, a set of front and rear side cameras and ultrasound sensors).

The Mmarket value of Tesla Inc. valuates at USD 60.0 billion, and according to plans in ten years is expected to reach even USD 650.0 billion. The implementation of this plan would not be possible only on the basis of the production of luxury electric cars. In addition, if they manage to enter the market as the first enterprise producer of autonomous vehicles, their self-driving vehicle technology will guide the development of the entire industry. And the 
position of Tesla Inc. can be confirmed by the strategy of facilitated lending of patents and licenses to interested entities.

To sum up, the main source of financing work on an the self-driving vehicle is financed from an increase in operating liabilities, issue of debt securities, additional payments to share capital, or and even revenues from the sale of $\mathrm{CO}_{2}$ emission rights, and external market sources, i.e. issues of shares on the stock exchange. Investors' expectations have already been reflected in the price of shares. A summary of selected information on project financing is presented below in the following Table 1.

Table 1. A summary of information on the self-driving vehicle by Tesla Inc. in 2015-2018

\begin{tabular}{|l|r|}
\hline Company name & Tesla Inc. \\
\hline Innovative product & self-driving vehicle \\
\hline Character of innovation & basic \\
\hline Level of complexity & innovations \\
\hline Importance of innovation & pioneering \\
\hline Impact of innovation on the market & radical \\
\hline Source of innovation & inventive activity and research \\
\hline Phase of innovation process & industrial research \\
\hline Type of innovation & technical and technological \\
\hline Assessment of innovation level & global \\
\hline Main obstacles to innovation & technology \\
\hline $\begin{array}{l}\text { Total cost of investment (USD) } \\
\text { *inventory (2018-3,113,446, 2017 - 2,263,537, 2016 - } \\
2,067,454,2015 \text { - 1,277,838) }\end{array}$ & $8,722,275.00$ \\
\hline Dependence on external sources of financing & $0.0 \%$ \\
\hline
\end{tabular}

Source: own study based on Tesla Inc. balance sheets in 2015-2018

The thermographic tester for oncological diagnostics

The BRASTER company was established in 2008 by five scientists associated with the Military University of Technology in Warsaw in order to conduct industrial research on the use of liquid crystal matrices for imaging disease lesions. These studies were financed from the resources of the State Agency for Enterprise Development as part of the funds of the Innovative Economy Operational Program (POIG 1.4-4.1).

The company was transformed into a joint-stock company and debuted on the Warsaw Stock Exchange's NewConnect market in 2011. In the same year, the Research and Development Laboratory was created.

The company was recapitalized by selling subsequent series of shares on the Warsaw Stock Exchange in 2011-2012. The next year, clinical research was conducted on the possibilities of diagnosing breast cancer with the consent of the Jagiellonian University Bioethics Committee. The company continued to regularly introduce further series of shares on the Warsaw Stock Exchange. Product development accelerated, including cooperation with the Warsaw University of Technology on a medical examination interpretation algorithm. Moreover, 
a liquid crystal matrix production line was delivered to the plant in Szeligi near Warsaw and work on developing applications and software to improve sensitivity parameters began in cooperation with the Warsaw University of Technology.

In 2016 industrial research, development works and patent procedures were completed and a production line was launched in Szeligi, allowing for the sale of products to begin. The company's management adopted for 2015-2021 a development strategy that aims at foreign expansion. By the end of this year, the company was the sole owner of 4 trademarks and 4 patents for liquid crystal imaging of lesions, as well as the ROSTI Polska company based in Bialystok, which deals with the production of components, the search for and purchase of electronic components and assembly.

On December 31, 2017, 71.11\% of BRASTER S.A. was owned by small stock investors, as well as Investors TFI S.A. (10.28\%), AVIVA TFI S.A. (9.78\%) and PZU S.A. (8.83\%). The company is currently looking for foreign investors.

In 2011-2017, the company worked hard to obtain financing for ongoing investments. The funds raised increased the company's capital. The company recorded the first sales revenue of PLN 427,000 in 2016, but in 2017 it fell to PLN 397,000. In the entire audited period, the company's operations were unprofitable, and the total loss by the end of 2017 summed up to PLN 27,706,000.

For these reasons ratio analysis in this period is extremely difficult to carry out for BRASTER S.A. Due to the unprofitable activity, the ROE (return on equity), ROA (return on assets) and ROS (return on sale) ratios are below 0 [Zalewska 2005, pp. 8386]. However, the current liquidity ratio is definitely above the norm. A. Hołda's early warning indicator also indicates the company's possible financial liquidity [Zalewska 2005, p. 134]. Meanwhile, J. Gałka and D. Stody's early warning indicator [Zalewska 2005 , p. 133] indicates that the project was not profitable. In the audited period, the net working capital, i.e. the company's liquid reserve, is also very high [Zalewska 2005, p. 56]. Moreover, in 2016-2018 the company showed an almost continuous decline in the value of short-term investments in the form of securities, which could have been a shortterm source of financing. 
Table 2. Selected analytical market indicators for BRASTER S.A. for 2011-2017

\begin{tabular}{|c|c|c|c|c|c|c|c|c|c|}
\hline \multicolumn{3}{|c|}{ Analysis of selected market indicators } & 2011 & 2012 & 2013 & 2014 & 2015 & 2016 & 2017 \\
\hline \multicolumn{3}{|c|}{ Number of employees } & 5 & 9 & 10 & 12 & 22 & 53 & 63 \\
\hline \multirow{2}{*}{$\mathrm{ROE}=$} & financialresult & \multirow{2}{*}{$* 100 \%$} & \multirow{2}{*}{-4.8} & \multirow{2}{*}{-0.2} & \multirow{2}{*}{-0.5} & \multirow{2}{*}{-0.4} & \multirow{2}{*}{-0.1} & \multirow{2}{*}{-0.4} & \multirow{2}{*}{-0.5} \\
\hline & equity & & & & & & & & \\
\hline \multirow{2}{*}{$\mathrm{ROA}=$} & financialresult & \multirow{2}{*}{ * $100 \%$} & \multirow{2}{*}{-0.4} & \multirow{2}{*}{-0.2} & \multirow{2}{*}{-0.5} & \multirow{2}{*}{-0.2} & \multirow{2}{*}{-0.1} & \multirow{2}{*}{-0.2} & \multirow{2}{*}{-0.3} \\
\hline & totalassets & & & & & & & & \\
\hline \multirow[b]{2}{*}{ ROS $=$} & financialresult & \multirow[b]{2}{*}{${ }^{*} 100 \%$} & \multirow[b]{2}{*}{ - } & \multirow[b]{2}{*}{-} & \multirow[b]{2}{*}{-} & \multirow[b]{2}{*}{-} & \multirow[b]{2}{*}{-} & \multirow[b]{2}{*}{-33.7} & \multirow[b]{2}{*}{-62.7} \\
\hline & $\begin{array}{c}\text { revenues from } \\
\text { sales }\end{array}$ & & & & & & & & \\
\hline \multirow{2}{*}{$\begin{array}{l}\text { Currentfluency } \\
\text { ratio }=\langle 1.2-2.0\rangle\end{array}$} & \multirow{2}{*}{\multicolumn{2}{|c|}{$\begin{array}{c}\text { currentassets } \\
\text { currentliabilities }\end{array}$}} & \multirow{2}{*}{0} & \multirow{2}{*}{53} & \multirow{2}{*}{30} & \multirow{2}{*}{38} & & & \\
\hline & & & & & & & 86 & 2 & 11 \\
\hline Chom fliobilitio & $\begin{array}{c}\text { currentliabilitie } \\
\text { s }\end{array}$ & $* 100 \%$ & 07 & 0 & 2 & 01 & 01 & 04 & 01 \\
\hline & totalliabilities & & & & & & & & \\
\hline Indicator of & current profit & & & & & & & & \\
\hline $\begin{array}{l}\text { covering loss from } \\
\text { previous years = }\end{array}$ & $\begin{array}{c}\text { loss from } \\
\text { previousyears }\end{array}$ & & - & 1.3 & 1.0 & 0.6 & 0.4 & 1.1 & 0.9 \\
\hline Net working ca & tal (in thousand I & N) & -336 & 6,691 & 3,565 & 10,234 & 31,210 & 13,869 & 33,475 \\
\hline Early warning indi & tor - J.Gajka and & Stoda & -414 & -206 & -256 & -2.861 & -3.371 & -17.856 & -14.794 \\
\hline Early warning & ndicator - A. Hoł & & 1 & 37 & 21 & 260 & 59 & 2 & 8 \\
\hline Price of 1 share or & he WSE on 31.12 & PLN) & $\mathrm{n} / \mathrm{a}$ & 11.00 & 3.50 & 7.99 & 13.35 & 18.00 & 6.91 \\
\hline
\end{tabular}

Source: own study based on the financial statements of BRASTER S.A. for 2012-2017

The price of shares on the Warsaw Stock Exchange during this period was subject to significant fluctuations: up to PLN 11.00 at the end of 2012, through PLN 18.00 at the end of 2016, while on January 31, 2019 the price was only PLN 1.65.

Despite this, in 2017-2018 BRASTER S.A. began activities focused on sales on foreign markets. The company plans to enter individual markets gradually, at short intervals. First, they are going to enter European countries, the United States of America and Canada, then Asia and Latin America. A central element of the marketing strategy are international fairs. The company intends to conduct primarily foreign expansion in cooperation with licensed distributors, who will also deal with comprehensive sales, logistics and, above all, local marketing.

According to the company's calculations, further expansion to foreign markets will require the acquisition of an additional PLN 66.3 million. The final product is expected to reach 300,000 Polish women and 21.2 million women around the world.

It can be concluded that the company, by researching ways of detecting breast disease conditions, is conducting further industrial research concerning expanding diagnostics using liquid crystal technology. Perhaps they plan to create a device that monitors all organs and limbs. In that case the profitability of the enterprise would be much higher.

To sum up, work on the thermographic tester was financed from various sources at various stages. At first, these were public funds for clinical trials. In 2015-2017, capital accumulation, 
from PLN 47.6 million to PLN 73.6 million, resulted from issuing shares and taking bank loans which was followed by decapitalization in 2018 to PLN 54.5 million. This indicates that the company is still learning how to invest. Data disclosed in the financial statements may indicate agreat potential on the part of the invention. A summary of selected information on the project's financing is presented in Table 3 below.

Table 3. A summary of information about BRASTER S.A.'s innovation (2011-2017)

\begin{tabular}{|l|r|}
\hline Name of company & BRASTER S.A. \\
\hline Innovative product & thermographic tester for oncological diagnostics \\
\hline Nature of innovation & basic \\
\hline Degree of complexity of innovation & innovation \\
\hline Importance of innovation & pioneering \\
\hline Impact of innovation on the market & radical \\
\hline Innovation source & inventions and research \\
\hline Phase of the process of innovation & commercialization \\
\hline Typeinnovation & technical and technological \\
\hline Assessment of the level of innovation & limitedresources \\
\hline Mainobstacles to innovation & $176,264,800.00$ \\
\hline Total cost of investment (PLN), of which: & $10,140,900.00$ \\
\hline 1. Public sources, of which: & $10,140,900.00$ \\
\hline Grants (PLN) & $99,823,900.00$ \\
\hline 2. Privatefinancing, of which: & $99,823,900.00$ \\
\hline Sharesissuing (PLN) & 0.00 \\
\hline 3. Fiscalfinancing (PLN) & $94,300,000.00$ \\
\hline 4. Further need for resources (PLN) & $94.2 \%$ \\
\hline Dependence on external sources of financing & worde \\
\hline
\end{tabular}

Source: own study based on BRASTER S.A. 2012-2017 balance sheets and Development Strategy

\section{Summary}

The Tesla Motors start-up was founded in 2003 in Silicon Valley. After spectacular success with electric cars in 2014, it became involved in a project to develop self-driving vehicle technology and began installing the Autopilot system. According to recent press information, the first model is to be produced in 2019. And the Autopilot system is to give the possibility of installing the autonomous system in earlier versions of the car in the future. Work on a selfdriving vehicle is financed by increasing operational obligations, issuing debt securities, additional capital contributions, and even from the sale of $\mathrm{CO}_{2}$ emission rights. The market value of Tesla Inc. valuates at USD 60.0 billion, and according to plans in ten years is expected to reach even USD 650.0 billion. In addition, if they manage to enter the market as the first 
producer of autonomous vehicles, their self-driving technology will guide the development of the entire industry.

BRASTER was established in 2008 as a company of five scientists associated with the Military University of Technology in Warsaw to undertake industrial research on the use of liquid crystal matrices to visualize disease lesions. It was transformed into a joint-stock company and debuted on the Warsaw Stock Exchange's NewConnect market in 2011. Carrying out work on introducing the oncological tester on the market, the company accumulated capital as a result of large share issues and taking out bank loans, which indicates that it is learning investment processes. Currently, BRASTER S.A. is focusing on entering foreign markets at short intervals - at first European countries, then the United States of America and Canada and finally Asia and Latin America. The final product is expected to reach 300,000 Polish women and 21.2 million women around the world.

\section{References}

Analiza techniczna - wprowadzenie, 2001, Reuters, Kraków.

Biała Księga Innowacji, 2016, Ministerstwo Nauki i Szkolnictwa Wyższego, Warszawa.

Brzeziński M., 2001, Zarządzanie innowacjami technologicznymi iorganizacyjnymi, Wydawnictwo Difin S.A., Warszawa.

Dąbrowska-Gruszczyńska K., 2017, Techniki japońskie w warsztacie polskiego inwestora giełdowego. Czy formacje świecowe moga pomóc przewidzieć zmiane trendu [in:] T. Czerwińska, A. Z. Nowak (eds.), Rynek kapitałowy - szanse i bariery, Wydawnictwo Naukowe Wydziału Zarządzania UW, Warszawa.

Druker P., 1992, Innowacja i przedsiębiorczość: praktyka z zasady, Państwowe Wydawnictwo Ekonomiczne, Warszawa.

Działalność innowacyjna przedsiębiorstw w latach 2015-2017, 2018, Główny Urząd Statystyczny, Warszawa.

Florida R., 2010, Narodziny klasy kreatywnej, Narodowe Centrum Kultury, Warszawa.

Głodek P., Pietras P., 2011a, Finansowanie przedsięwzięć innowacyjnych w MSP, Polska Agencja Rozwoju Przedsiębiorczości, Łódź.

Głodek P., Pietras P., 2011b, Źródła finansowania dla komercjalizacji technologii i wiedzy, Polska Agencja Rozwoju Przedsiębiorczości, Łódź. 
Gocławska-Bolek J., 2014, Innowacyjność gospodarcza i społeczna jako strategia rozwoju Ameryki Łacińskiej w perspektywie historycznej, Studia prawno-ekonomiczne, XCII, pp. 263-280.

Gomułka S. 1998, Teoria innowacji i wzrostu gospodarczego, Centrum Analiz SpołecznoEkonomicznych, Warszawa.

Gorzelak G., Bąkowski A., Kozak M., Olechnicka A., 2006, Polskie Regionalne Strategie Innowacji: ocena i wnioski dla dalszych działań, Ministerstwo Gospodarki, Departament Rozwoju Gospodarki, Warszawa.

Kawalec P., 2017, Rola finansów publicznych w stymulowaniu innowacji [in:] Nowe tendencje w zarzadzaniu, Wydawnictwo KUL, Lublin.

Kokot-Stępień P., 2016, Finansowanie działalności innowacyjnej przedsiębiorstw w Polsce. Zarządzanie Nr 24 t.1, Częstochowa.

Komisja Europejska. Biała Księga w sprawie przyszłości Europy. (COM 2017).

Komisja Europejska. Zielona Księga. (COM 2011).

Kozioł-Nadolna K., 2015, Crowdfunding jako źródło finansowania innowacyjnych projektów, Zeszyty Naukowe Uniwersytetu Szczecińskiego, 854, Finanse, Rynki Finansowe, Ubezpieczenia, 73, Wydawnictwo Naukowe Uniwersytetu Szczecińskiego, Szczecin, pp. 671-683.

Król K., 2013, Crowdfunding. Od pomysłu do biznesu, dzięki społeczności, Crowfunding.pl, Warszawa.

Kubielas S., 2009, Innowacje i luka technologiczna w gospodarce globalnej opartej na wiedzy: strukturalne i makroekonomiczne uwarunkowania, Wydział Nauk Ekonomicznych UW, Warszawa.

Kuciński A., 2011, Rynek NewConnect jako źródło kapitału dla przedsiębiorstw, Zeszyty Naukowe Uniwersytetu Szczecińskiego, 637, Ekonomiczne Problemy Usług, 62, pp. 207-216.

Nehrebecka N., Białek-Jaworska A., 2015, Czy źródła finansowania wpływaja na efektywność inwestycji w środki trwate i B+R?, Metody Ilościowe w Badaniach Ekonomicznych, XVI, 4, pp. 64-74.

Piech K., 2009, Wiedza i innowacje w rozwoju gospodarczym: w kierunku pomiaru i wspótczesnej roli państwa, Instytut Wiedzy i Innowacji, Warszawa.

Podręcznik Oslo: Zasady gromadzenia i interpretacji danych dotyczacych innowacji, 2005, Wydanie trzecie, OECD, Komisja Europejska. 
Weresa M. A., Kowalski A. M., 2018, Polska. Raport o konkurencyjności 2018. Rola miast w kształtowaniu przewag konkurencyjnych Polski, Oficyna Wydawnicza SGH, Warszawa.

Program Operacyjny Wiedza Edukacja Rozwój 2014-2020, 2018, Ministerstwo Inwestycji i Rozwoju, Warszawa.

Prospekt emisyjny. Oferta publiczna akcji serii I. Braster, Lipiec 2017.

Rumelt R., 2013, Dobra strategia, zła strategia. Czym się różnia i jakie to ma znaczenie, MT Biznes, Warszawa.

Sprawozdanie finansowe BRASTER S.A. za 2012 rok, 2013, Szeligi.

Sprawozdanie finansowe BRASTER S.A. za 2013 rok, 2014, Warszawa.

Sprawozdanie finansowe BRASTER S.A. za 2014 rok, 2015, Szeligi.

Sprawozdanie finansowe BRASTER S.A. za 2015 rok, 2016, Szeligi.

Sprawozdanie finansowe BRASTER S.A. za 2016 rok, 2017, Szeligi.

Sprawozdanie finansowe BRASTER S.A. za 2017 rok, 2018 , Szeligi.

Szczegółowy opis osi priorytetowych Programu Operacyjnego Polska Wschodnia 2014-2020, 2019, Warszawa.

Szul E., 2011, Anioły biznesu - ich znaczenie w rozwoju przedsiębiorczości, Nierówności Społeczne a Wzrost Gospodarczy, 18, pp. 323-334.

Świtalski W., 2005, Innowacje i konkurencyjność, Wydawnictwa Uniwersytetu Warszawskiego, Warszawa.

Zalewska M., 2005, Ocena ekonomiczno-finansowa przedsiębiorstwa przez analityka bankowego, Wydawnictwo Szkoła Główna Handlowa, Warszawa.

\section{Web pages}

http://instrumentyfinansoweue.gov.pl/program-cosme/

http://instrumentyfinansoweue.gov.pl/program-horyzont-2020/

https://www.kickstarter.com/help/stats

https://www.poir.gov.pl/strony/o-programie/ 


\section{STRESZCZENIE}

Cel

Celem niniejszego artykułu jest scharakteryzowanie działalności innowacyjnej przedsiębiorstw pod względem źródeł jej finansowania. Uzyskanie wystarczających środków pieniężnych jest nieodzownym i podstawowym wymogiem podjęcia dowolnej działalności inwestycyjnej, a ponadto w dużej mierze warunkuje dalszy przebieg procesu inwestycyjnego oraz wpływa na decyzje w kolejnych etapach. Przekrojowe omówienie dostępnych źródeł finansowania działalności innowacyjnej pozwala uchwycić współzależności pomiędzy przedmiotem wprowadzanych przez przedsiębiorstwo innowacji a strukturą jego finansowania. Przedstawione zostaną zarówno aspekty teoretyczne przedmiotowego zagadnienia, jak i praktyczne funkcjonowanie dwóch wybranych spółek zajmujących się wdrażaniem produktów innowacyjnych.

\section{Konstrukcja i metodologia}

W pracy postawiono hipotezę zakładająca, że specyfika współczesnej działalności innowacyjnej narzuca formy finansowania zapewniające wysoki poziom kapitału oraz elastyczne zasady jego pozyskiwania, którą zweryfikowano w drodze przeglądu literatury oraz analizy innowacyjnych produktów i spółek.

Artykuł składa się z trzech części. Pierwsza ma na celu zdefiniowanie pojęcia innowacji oraz scharakteryzowanie poszczególnych typów innowacji: technologicznych, organizacyjnych i społecznych. Omówiono także cechy specyficzne zjawiska innowacyjności, uwarunkowania je kształtujące oraz wpływ, jaki wywiera ono na wzrost gospodarczy.

Część druga stanowi przegląd istniejących źródeł i metod pozyskiwania kapitału w podziale na instrumenty rynkowe oraz instrumenty publiczne. Omówione zostały uwarunkowania stosowania poszczególnych instrumentów w zależności od etapu rozwoju przedsiębiorstwa, a także ich potencjalne zalety oraz ograniczenia z punktu widzenia przedsiębiorcy.

W części trzeciej poddano analizie innowacyjne produkty oraz przedsiębiorstwa odpowiedzialne za ich powstanie i rozwój: samochód autonomiczny stworzony przez amerykańską spółkę Tesla Inc. oraz tester termograficzny do diagnostyki onkologicznej stworzony przez polską spółkę BRASTER.

\section{Wnioski i podsumowanie}

Innowacyjność nadal należy do rozwijającej się dziedziny gospodarki i ekonomii. Badania statystyczne i ekonometryczne dowodza, że z uwagi na znaczne ryzyko, konieczna jest stymulacja tej dziedziny. A jej rozwój przekłada się zarówno na wzrost PKB, jak i poprawę warunków bytowych. Jednak, aby nadążanie za granicą technologiczną było możliwe, konieczne jest podejmowanie trafnych działań w celu zmniejszania luki technologicznej. 
Mając powyższe na uwadze, finansowanie innowacyjności jest procesem złożonym i wieloetapowym, wymagającym elastycznego podejścia przy podejmowaniu działań inwestycyjnych. Z tego powodu istnieje znaczna różnorodność dedykowanych innowacjom instrumentów finansowych oferowanych przez podmioty rynkowe oraz przez instytucje państwowe.

Rozważania teoretyczne uzupełniono o omówienie wybranych przykładów spółek wdrażających zaawansowane technologicznie produkty. Tesla Inc. finansuje prace nad samochodem autonomicznym poprzez zwiększenie zobowiązań operacyjnych, emisję dłużnych papierów wartościowych, dopłaty do kapitału zakładowego, a nawet ze sprzedaży praw do emisji $\mathrm{CO}_{2}$. Natomiast BRASTER S.A., prowadząc prace nad wprowadzeniem na rynek testera onkologicznego, dokonała akumulacji kapitału, w wyniku dużych emisji akcji oraz zaciągnięcia kredytów bankowych, co wskazuje, że Spółka dopiero uczy się procesów inwestycyjnych.

Słowa kluczwe: innowacja, źródła finansowania innowacji, samochód autonomiczny, onkologiczny tester termograficzny


in cycling and new technology, as a hobby learns English, Deutsche and French, contact: mail: joanna.wodzynska@wp.eu. Joanna Wodzyńska - absolwentka studiów magisterskich Szkoły Głównej Handlowej w Warszawie w zakresie rachunkowości, ekspert w zakresie rynku pracy oraz trzeciego sektora, z zamiłowania rowerzysta i technik informatyk, a hobbystycznie uczy się angielskiego, niemieckiego i francuskiego, kontakt:joanna.wodzynska@wp.eu.
}

Rafał Czyżewski - graduate in international relations in Maria Sklodowska-Curie University in Lublin, specialist of public finances, accountancy and EU programmes, contact: rafal.m.czyzewski@gmail.com

Rafał Czyżewski - absolwent stosunków międzynarodowych na Uniwersytecie Marii Skłodowskiej-Curie w Lublinie, specjalista w zakresie finansów publicznych, rachunkowości jednostek sektora finansów publicznych oraz programów realizowanych z udziałem środków UE, kontakt: rafal.m.czyzewski@gmail.com 